\author{
Al-wardah: Jurnal Kajian Perempuan, Gender dan Agama \\ Volume: 12 Nomor: 1 \\ ISSN: 1907-2740, E-ISSN: 2613-9367 \\ DOI: $\mathrm{xxx} \mathrm{xxxx} \mathrm{xxxx}$
}

\title{
PEREMPUAN DALAM GERAKAN TERORISME DI INDONESIA
}

\author{
Musdah Mulia \\ Univ Islam Negeri Syarif Hidayatullah,Indonesia \\ E-mail:m-mulia@indo.net.id atau icrp@cbn.net.id
}

\begin{abstract}
The new mode of terrorism is making women as perpetrators. If previously terrorist acts had a masculine face and used a patriarchal approach, later terrorist acts made use of women as perpetrators and with a feminine approach. Despite the fact that women are perpetrators, in essence they remain victims. This paper tries to uncover various matters related to the involvement of Muslim women in terrorism movements in Indonesia. Among other things, explore the background of their lives, what are their main motives involved in acts of terrorism, why this violent and deadly movement actually appeals to women groups who are generally gender biased and are still perceived as vulnerable groups and domestic creatures., women are more easily recruited as agents of peace (agent of disengagement). If they can be recruited as terrorists it should be easier to invite them to become agents of peace. Because naturally women are created with a womb to care for the continuity of human life. Keywords: Women, Terrorism Movement
\end{abstract}

\section{Abstrak}

Modus baru dalam aksi terorisme menjadikan perempuan sebagai pelaku. Kalau sebelumnya aksi-aksi teror berwajah maskulin dan menggunakan pendekatan patriarkal, belakangan aksi-aksi teror memanfaatkan perempuan sebagai pelaku dan dengan pendekatan feminin. Meskipun faktanya perempuan adalah pelaku, hakikinya mereka tetap korban.Tulisan ini mencoba menguak berbagai hal terkait keterlibatan perempuan Muslim dalam gerakan terorisme di Indonesia. Di antaranya, menggali latar-belakang kehidupan mereka, apa motif utama mereka terlibat dalam aksi-aksi terorisme, mengapa gerakan yang penuh kekerasan dan mematikan ini justru menarik bagi kelompok perempuan yang umumnya secara bias gender masih dipersepsikan sebagai kelompok rentan dan makhluk domestik.Sesuai kodratnya, perempuan lebih mudah direkrut menjadi agen perdamaian (agent of disengagement). Kalau mereka bisa direkrut menjadi teroris seharusnya lebih mudah mengajak mereka menjadi agen perdamaian. Karena secara alami perempuan diciptakan dengan sebuah rahim untuk merawat keberlangsungan kehidupan manusia.

Kata Kunci : Perempuan, Gerakan Terorisme

\section{A. PENDAHULUAN}

\section{Modus baru}

Keberadaan perempuan sebagai teroris di Indonesia mulai terkuak dengan tertangkapnya Dian Yulia Novi, pelaku "bom panci” di Bekasi di penghujung 2016. 
Perempuan Dalam Gerakan...

Tragedi ini menyibak fakta keterlibatan sejumlah perempuan dalam gerakan terorisme di Indonesia.

Setelah Dian, muncul nama Ika Puspita Sari di Purworejo yang akan melancarkan aksi bom bunuh diri di luar Jawa. Lalu, Umi Delima, isteri teroris Santoso di Poso. Penangkapan ketiga orang tersebut menambah jumlah nama perempuan dalam pusaran terorisme. Di antara beberapa nama yang tertangkap sebelumnya, yaitu Putri Munawwaroh, Inggrid Wahyu, Munfiatun, Rasidah binti Subari, Ruqayah binti Husen Lecano, Deni Carmelit, Rosmawati, dan Arina Rahma.

Modus baru dalam aksi terorisme menjadikan perempuan sebagai pelaku. Kalau sebelumnya aksi-aksi teror berwajah maskulin dan menggunakan pendekatan patriarkal, belakangan aksi-aksi teror memanfaatkan perempuan sebagai pelaku dan dengan pendekatan feminin. Meskipun faktanya perempuan adalah pelaku, hakikinya mereka tetap korban. Korban dari ketidaktahuan dan ketidakberdayaan, lalu dimanfaatkan oleh pihakpihak yang memiliki rencana keji dan sistematik untuk tujuan terorisme.

Kasus-kasus terorisme belakangan ini menempatkan perempuan bukan lagi sebagai "pemain pembantu" yang menyiapkan logistik dan perlengkapan perang, akan tetapi sudah "naik kelas" menjadi eksekutor dan pasukan perang. Bahkan, beberapa perempuan menjadi aktor kunci pemenangan aksi terorisme.

Tulisan ini mencoba menguak berbagai hal terkait keterlibatan perempuan Muslim dalam gerakan terorisme di Indonesia. Di antaranya, menggali latar-belakang kehidupan mereka, apa motif utama mereka terlibat dalam aksi-aksi terorisme, mengapa gerakan yang penuh kekerasan dan mematikan ini justru menarik bagi kelompok perempuan yang umumnya secara bias gender masih dipersepsikan sebagai kelompok rentan dan makhluk domestik. Selain itu, penulis juga memaparkan beragam pengalaman perempuan selama aktif dalam dunia terorisme. Lalu, tulisan ini juga menawarkan kesimpulan dan solusi konkret untuk menghadang laju gerakan terorisme di Indonesia. 


\section{Perempuan sebagai korban terorisme}

Jauh sebelum perempuan dilibatkan sebagai pelaku dalam aksi-aksi terorisme, mereka telah lama dijadikan sasaran utama dan pertama dalam berbagai aksi-aksi kebrutalan terorisme. Akibat budaya patriarki yang masih mengental di masyarakat, perempuan selain dipandang sebagai kelompok rentan dan tak berdaya, mereka juga dianggap sebagai simbol kemurnian sebuah kelompok. Asumsi ini membuat kelompokkelompok teroris memilih mereka sebagai sandera atau korban berbagai bentuk kekerasan seksual untuk menyebarkan rasa takut dan memicu penyerahan diri target-target sebenarnya. Lihat saja apa yang dilakukan Boko Haram di Nigeria, kelompok terorisme di Suriah, Irak, Lebanon, Pakistan dan Afghanistan.

Di Nigeria pada 2014, kelompok Islam garis keras Boko Haram dilaporkan menculik ratusan siswi dalam aksi terornya. Mereka meyakini, sistem pendidikan Barat merupakan dosa dan perempuan tidak perlu pendidikan. Mereka cukup di rumah membesarkan anak dan melayani suami. Tidak hanya menculik, Boko Haram juga melakukan pengeboman sekolah-sekolah yang menewaskan ratusan pelajar.

Hampir seabad sebelumnya, pada 1917 di Amerika Serikat terjadi teror dan penyiksaan terhadap para perempuan yang memperjuangkan hak-hak asasi mereka sebagai warga negara. Ketika itu hak pilih perempuan belum diakui di sana dan sejumlah aktivis feminisme ditangkap dan dianiaya secara keji di penjara. Mereka dianiaya setelah melancarkan protes di Gedung Putih karena tidak diperbolehkan mengikuti pemilihan umum. Tragedi ini diperingati sebagai The Night of Terror.

Masih di Amerika, aktivis anti-aborsi garis keras melancarkan teror untuk mengakhiri praktik legal pengguguran bayi sejak 1973.RAND researcher menginformasikan, sampai tahun 2003 sejak hak perempuan melakukan aborsi diakui, tercatat lebih dari 300 aksi kekerasan yang sangat biadab terhadap para penyedia jasa aborsi dalam bentuk pembakaran dan pengeboman klinik, pembunuhan tenaga medis, sampai penyerangan dengan asam butirat. National Abortion Federation mencatat, sejak 1977 
hingga 2016, terjadi 11 kasus pembunuhan, ditemukan sejumlah 69.191 email kebencian dan pelecehan, 42 pengeboman klinik, 252.470 protes yang menghambat para pekerja klinik aborsi beraktivitas, dan aksi kekerasan lain yang dilakukan aktivis anti-aborsi di Amerika Serikat.

Perempuan sebagai korban terorisme tidak hanya mereka yang bersinggungan langsung dengan pelaku. Para perempuan Muslim pasca tragedi 11 September juga menjadi korban tak langsung. Pasalnya, sejak aksi terorisme tersebut, mereka kerap kali dilekatkan dengan stereotip negatif. Sebagian mereka menerima perlakuan diskriminatif atau perundungan di lingkungan masyarakatnya hanya karena mengenakan jilbab. Berbagai fenomena tadi memberikan bukti betapa perempuan merupakan kelompok paling rentan dan sekaligus menjadi sasaran empuk aksi-aksi terorisme.

\section{Perempuan teroris di tingkat internasional}

Jika sebelumnya dijelaskan kondisi perempuan sebagai obyek dan korban gerakan terorisme, berikut ini peran sebaliknya, yakni sebagai subyek atau pelaku. Di tingkat internasional keterlibatan perempuan sebagai subyek atau pelaku dalam aksi terorisme sudah berlangsung lama, bahkan beberapa di antara mereka dipandang sebagai kunci kesuksesan kelompok teroris.

Pada pengujung abad 19, Vera Zasulich, seorang perempuan Rusia yang tercatat sebagai anggota kelompok revolusioner Narodnaya Volia tidak gentar melakukan aksi teror dengan mencoba membunuh Trepov, Gubernur St. Petersburg. Saat berada di pengadilan, Zasulich mengatakan dirinya bukan pembunuh, tetapi dengan bangga menyebut: "saya adalah teroris." Shcheblanova dan Yarskaya-Smirnova (2009), keduanya penulis dalam buku Gender Dynamics and Post-conflict Reconstruction menyatakan bahwa sekalipun Zasulich melakukan aksi teror, namun tetap dielukan sebagai pahlawan oleh publik karena berani melawan ketidakadilan sosial.

Selain di Rusia, Irlandia Utara dimana IRA berada, yaitu organisasi yang menuntut independensi Irlandia dari Kerajaan Inggris, juga melibatkan para perempuan mendukung 
aksi-aksi teror mereka. Dua nama tercatat sebagai perempuan pemberani yang turut dalam aksi pengeboman: Marian dan Dolores Price. Tahun 1973, mereka dijatuhi hukuman seumur hidup atas pengeboman di Old Bailey yang menyebabkan 216 orang luka-luka dan seorang meninggal.

Selanjutnya, Lindsey O'Rourke dari University of Chicago mencatat sejak tahun 1980 di Lebanon, perempuan ambil andil dalam aksi terorisme untuk mengusir pasukan Israel. Sementara itu, di Chechnya mulai tahun 2000-an, kelompok Black Widows berani melakukan aksi serangan bunuh diri sebagai balas dendam atas kematian suami mereka. (Speckhard, Anne and Khapta Akhmedova:.2004)

Hannah Arendt, pemikir Jerman berpendapat bahwa akar dari terorisme adalah “perasaan ditinggalkan.” Lebih jauh menurut Arendt, manusia kalah dari kehidupan modern (Arendt, Hannah:1968). Terorisme muncul, karena manusia tidak berdaya atas "prestasi peradaban" yang ironisnya telah diciptakan oleh dirinya sendiri. Manusia tergerus oleh arus kuat modernisasi dan globalisasi yang kemudian menghapus cara-cara hidup tradisional, adat-istiadat, kebiasaan dan institusi yang mereka warisi turun-temurun. Perasaan "kalah" membawa kepada keterasingan atau alienasi dan perasaan tersingkirkan.

Ketika kalah bersaing dengan kemajuan modern banyak manusia terdepak dari pekerjaan. Kerja yang merupakan salah satu pengukur martabat manusia membuatnya tergeser secara sosial dari masyarakat. Mereka yang terasing pun keluar mencari perlindungan dari komunitas primordial semisal agama.

Mengapa agama? Karena agama menawarkan penghiburan dan ketetapan hati. Namun, karena tanpa kontrol dan ketundukan buta, manusia yang kalah dari peradaban tersebut kehilangan sikap kritis dan rasionalitasnya. Tidak heran jika kemudian mereka mudah diarahkan berontak kepada peradaban modern yang diklaim sebagai asal muasal segala kejahatan modern.

Faktor psikologis juga dinilai cukup berperan. Sejumlah penelitian mengungkapkan, para perempuan tersebut mengalami kekecewaan yang amat dalam, putus asa, mengalami gangguan jiwa, ditekan oleh laki-laki atas nama agama, frustrasi dengan kondisi 
ketidaksetaraan dan ketidakadilan gender yang ada, ketimpangan sosial di lingkungan mereka dan lain sebagainya. Faktor lain menyebutkan karena perempuan kurang dicurigai petugas keamanan. Lazimnya, perempuan menjalani proses pemeriksaan tidak lebih ketat daripada laki-laki saat berhadapan dengan petugas keamanan. Mereka sering kali dianggap tidak membahayakan sehingga petugas keamanan lengah dan insiden pengeboman yang dilakukan perempuan pun tidak terelakkan. Misalnya, aksi pengeboman yang sukses dilakukan seorang perempuan yang membawa anak-anak kecil untuk mengelabui petugas keamanan. Anak-anak kecil tersebut tampak malnutrisi sehingga petugas tidak merasa curiga terhadap perempuan yang membawa mereka. Setelah anak-anak tersebut dibawa ke dalam ambulans, sang perempuan teroris meledakkan diri dan mencederai lusinan orang.

Di Nigeria lain lagi kasusnya, di antara perempuan pelaku bom melakukan aksi terror tersebut karena dipaksa dan diancam, seperti terjadi pada perempuan-perempuan korban penculikan yang dilakukan kelompok Boko Haram. Sejumlah anak perempuan berusia 14 tahun pada akhirnya menjadi pelaku teror seperti bom bunuh diri. Salah seorang di antaranya selama tiga tahun disekap oleh Boko Haram dan beberapa kali dipaksa memenuhi syahwat relawan kelompok garis keras tersebut, tetapi terus menolak. Akibatnya, beberapa petinggi Boko Haram memaksa dia melakukan bom bunuh diri di pusat kekuatan militer di Maiduguri sebelum akhirnya tertangkap militer setempat. (Speckhard, Anne:2015)

\section{B. PEMBAHASAN}

Gelombang modernisasi dan globalisasi mendorong rasa kecewa yang menyelimuti individu-individu yang tidak begitu beruntung dalam percaturan politik yang terjadi pada ranah negara-bangsa ke titik ekstrem; krisis identitas. Berbasis jaringan global yang semakin ketat, tempat lokalitas dan identitas personal terkikis, globalisasi mengacaukan mekanisme kontrol sosial dan representasi politik yang ada. Ketika sistem politik nationstate tidak bekerja sebagaimana mesinya, baik karena lemahnya sistem akuntabilitas dan transparansi maupun merajalelanya korupsi, globalisasi tak pelak menghadapkan orang pada penderitaan dan kesengsaraan. 
Oleh karena itu, tidak mengejutkan jika banyak individu cenderung merasa kehilangan kendali atas kehidupannya, lingkungan, pekerjaan, ekonomi, pemerintahan, negara, dan nasibnya di bumi ini. Dalam situasi semacam itu bergabung dengan gerakan radikalisme kerap menjadi "pilihan rasional" bagi individu-individu yang kehilangan harapan akan masa depan. Gerakan radikalisme datang menawarkan jalan keluar ilusif dan sekaligus payung komunalitas alternatif melalui pengembangan enclave culture. Di dalamnya ada semacam kebanggaan karena merasa berbeda dari masyarakat terbuka (open society) di sekitarnya dan juga kemudian mereka seolah merasakan adanya harapan dan kepastian.

\section{Radikalisme mengeksploitasi perempuan}

Banyak penelitian menyimpulkan bahwa perempuan selalu berada dalam posisi sebagai korban manakala suatu masyarakat mengalami proses radikalisasi. Perempuan dalam agama apa pun selalu menjadi sasaran diskriminasi dan eksploitasi para penafsir fundamental yang benci pada perempuan (mysogini). Diskriminasi penafsiran, kata Karen Amstrong (Karen Armstrong :2003), dimulai ketika sejarah agama dipisahkan dari kontek historis dan raison de etre keyakinan individu pemeluknya.

Perempuan menjadi sasaran kelompok radikalisme agama dengan alasan yang sangat jelas. Sebab, atas nama agama, kelompok tersebut merasa memiliki legitimasi mengontrol dan menyerang perempuan. Selain legitimasi agama, mereka didukung pula oleh nilai-nilai budaya yang secara umum memang berwatak patriarkis dan bias gender. Tidak mengherankan jika suatu masyarakat atau negara mengalami radikalisasi, domestifikasi perempuan biasanya menjadi program politik pertama. Kondisi demikian tiada lain karena biaya sosial politik domestifikasi perempuan sangat murah dan mudah. Murah dan mudah karena dalam struktur masyarakat patriarki, proyek domestifikasi perempuan tidak akan mendapat resistensi sosial politik yang berarti.

Untuk kasus Indonesia, terlihat jelas bahwa dalam ranah negara, kelompok radikal mengimplementasikan Syariat Islam dalam berbagai bentuk peraturan dan kebijakan diskriminatif terhadap perempuan, seperti UU Pornografi, Peraturan Daerah tentang 
kewajiban berjilbab; Perda tentang larangan keluar malam bagi perempuan tanpa disertai mahram; Perda larangan prostitusi yang hanya mengarah kepada perempuan, dan sejumlah Qanun di Aceh, di antaranya Qanun Khalwat dan kewajiban berjilbab. Sementara dalam ranah masyarakat sipil, implementasi syariat Islam diwujudkan dalam bentuk fatwa MUI yang diskriminatif terhadap perempuan; munculnya organisasi dan LSM Islam yang visi dan misinya mengeksploitasi dan mengkriminalkan perempuan, seperti FPI, FBR, Majelis Mujahidin, Hizbut Tahrir, Lasykar Jundullah dan sejumlah Forum Umat Islam.

Dengan alasan pemurnian agama dan kembali kepada teks Al-Qur'an dan Hadits, radikalisme Islam menegaskan perbedaan hak antara laki-laki dan perempuan. Menurut mereka, Tuhan sengaja membuat keduanya berbeda dan perbedaan itu bukan diskriminasi melainkan demi kebahagiaan manusia. Kesimpulannya, radikalisme mengajak kembali kepada agama. Akan tetapi, dalam konteks perempuan yang diklaim sebagai kembali kepada ajaran agama adalah kembali merumahkan perempuan; kembali ke domestifikasi perempuan. Ringkasnya, radikalisme memproklamirkan politik anti demokrasi, antiPancasila, anti-konstitusi, anti feminisme, anti pluralisme, dan anti humanisme.

\section{Perempuan Indonesia dalam gerakan terorisme}

Walau keterlibatan perempuan dalam gerakan terorisme di Indonesia masih dianggap baru, namun Ali Fauzi berkeyakinan, sudah banyak perempuan disiapkan menjadi pengantin bom bunuh diri. Fenomena ini merupakan dampak krisis global dari aksi-aksi

teror level dunia yang banyak melibatkan perempuan, seperti di Syria, Irak, Afghanistan dan Yaman.

Jika sebelumnya perempuan Indonesia selalu menjadi korban pertama dan utama dalam berbagai aksi terorisme, kini posisi mereka bergeser tajam. Perempuan bukan lagi sekedar obyek dan korban dalam gerakan terorisme, melainkan mengalami transformasi yang luar biasa menjadi subyek dan bahkan tidak sedikit yang memainkan aktor utama gerakan terorisme. Pertanyaan kritis muncul, mengapa kelompok terorisme menjadikan perempuan sebagai subyek dan pelaku? 
Strategi dan taktik NIIS Internasional akhir-akhir ini menggunakan perempuan dalam peran-peran kombatan sebagai pasukan artileri dan pelaku bom bunuh diri. Tidak sulit mencari jawaban terhadap strategi tersebut. Wacana feminisme menyimpulkan, perempuan adalah kelompok paling diandalkan dalam soal loyalitas, kesetiaan dan kepatuhan. Perempuan juga adalah kelompok paling mudah percaya dan tunduk pada segala hal benuansa agama.

Sungguh ironis memang karena perempuan umumnya sangat bersahabat dengan agama, meski agama seringkali tidak ramah terhadap mereka. Selain itu, secara sosiologis perempuan adalah kelompok rentan (the vulnerable groups), mudah mengakses sosial media, tapi kemampuan literasi mereka sangat rendah. Tidak heran jika mereka menerima berita dan pelajaran keagamaan melalui situs-situs radikal tanpa nalar kritis. Mereka mudah diprovokasi atas nama agama.

Lihat saja, hampir semua pengajian dan majlis taklim di Indonesia dipenuhi kaum perempua. Padahal umumnya tafsir dan interpretasi keagamaan sangat misogini dan mengandung unsur-unsur diskriminatif terhadap perempuan. Bahkan, tidak sedikit pemuka agama memandang perempuan hanya sebatas obyek seksual. Selama ini perempuan dianggap lemah dan tidak berdaya sehingga posisinya cukup di arena domestik. Namun, keterlibatan perempuan dalam gerakan terorisme seharusnya mengubah pandangan misogini tersebut. Perempuan justru lebih nekat dan berani mengambil resiko dalam berbagai aksi teror.

\section{Motivasi utama perempuan dalam terorisme}

Motivasi utama perempuan Indonesia terlibat dalam gerakan terorisme adalah bersifat teologis. Awalnya, mereka terpapar ideologi Islam radikal, di antaranya keyakinan bahwa wajib hukumnya bagi seorang Muslim membunuh orang kafir (non-Muslim); meyakini kewajiban menegakkan negara Islam dan khilafahislamiyah dengan melakukan jihad menumpas ketidakadilan, walau dengan cara membunuh sekalipun. Mereka juga dijejali dengan narasi ketertindasan Islam sehingga sangat meyakini bahwa umat Islam kini 
Perempuan Dalam Gerakan...

dalam kondisi tertindas karena itu harus diselamatkan dengan jihad. Jihad dalam makna membunuh semua musuh Islam yang mereka istilahkan dengan thagut. Mereka juga didoktrin dengan pemahaman bahwa perempuan harus ikut berjihad membela Islam. Biasanya, dari radikalisme hanya perlu satu langkah menuju terorisme.

Fathali M. Moghaddam, pengamat gerakan terorisme menyebutkan ada empat tahapan yang biasanya dilalui oleh kelompok radikal Islam sebelum bermetaformosis menjadi teroris (Debbie Affianty :2107) Pertama, mereka memiliki keyakinan bahwa mereka teraniaya, terpinggirkan dan tidak berdaya. Keyakinan tersebut mendorong mereka mencari suatu pegangan demi memperbaiki kondisi. Kedua, keyakinan bahwa sudah saatnya dan sangat penting untuk melampiaskan kemarahan dan dendam kepada mereka yang dipersepsikan sebagai "thagut". Ketiga, keyakinan bahwa aksi terorisme merupakan strategi paling mungkin dan paling sah agar kemenangan segera tercapai. Keempat, munculnya keyakinan yang sangat kuat bahwa terorisme merupakan jihad terbesar untuk menjadi syahid, seperti bunyi slogan yang diajarkan: isy kariman aw mut syahidan (hiduplah secara terhormat atau matilah dengan syahid).

Di Indonesia, kelompok Islam radikal sangat mudah dikenali karena mereka sering mengusik tradisi keislaman yang sudah mapan dan diamalkan umat Islam di negeri ini, seperti tradisi pembacaan Barzanji, tahlilan dan dzibaan, tradisi peringatan maulid Nabi, tradisi takziyah kematian dan seterusnya. Selain itu, biasanya mereka gencar menyebarkan paham anti-Pancasila, anti-demokrasi, anti-kebhinekaan dan keberagaman, dan antikesetaraan gender. Mereka juga alergi dengan semua yang datang dari Barat dan non-Islam. Fatalnya lagi, mereka juga benci dengan simbol-simbol keindonesiaan, seperti bendera Merah-Putih, lambang Burung Garuda, dan lagu Indonesia Raya. Mereka menyebut semua itu bidah dan thagut (musuh Islam) yang harus dilenyapkan. Bahkan, mereka memandang Indonesia sebagai negara kafir karena itu boleh dirampok.( Zuly Qodir:2017)

Untuk kasus Indonesia, ada banyak hipotesis yang muncul mengapa para perempuan Indonesia bersedia melakukan tindakan terorisme. Salah satu faktor penyebab adalah lekatnya pengaruh dan strategi ISIS dalam jaringan teroris yang ada di Indonesia. 
Para laki-laki personil ISIS sudah banyak berkurang, kerena tertangkap maupun tewas dalam gencatan senjata. Untuk melanjutkan misi, maka anggota jaringan yang tersisa, umumnya mereka adalah perempuan, harus diterjunkan, tidak perduli anak-anak atau perempuan. Ternyata strategi yang dipakai oleh ISIS di tingkat dunia digunakan juga di Indonesia.

Menurut Bahrun Naim, pimpinan ISIS asal Indonesia, perlunya mengajak perempuan untuk ikut melakukan aksi terror karena hanya sedikit laki-laki yang bersedia. Lebih jauh dia mengatakan: "kalau di Suriah aksi amaliyah tidak wajib dilakukan oleh perempuan, tapi di Indonesia, perempuan boleh melakukan aksi teror karena laki-laki lebih pengecut." Hal itu terbaca dalam percakapan telegram pada Juni 2016. Faktor lain adalah karena perempuan dianggap lebih mudah dipengaruhi, terutama mereka yang memiliki masalah dalam keluarga. Selain itu, kaum perempuan dianggap sangat loyal pada ajaran dan ideologi agama, lebih militan dalam menjalankan aksinya. Apalagi mereka yang pernah mengalami trauma, menjadi korban KDRT atau mengalami konflik dalam keluarga atau perceraian. Ketika dicuci otak dengan pemahaman Islam radikal, para perempuan tersebut bisa dengan militan menjalankan misinya, bahkan lebih militan dari laki-laki.

\section{Figur perempuan teroris}

Perempuan seperti apa yang banyak terlibat dalam gerakan terorisme di Indonesia? Penelitian Yayasan Prasasti Perdamaian mengungkapkan, umumnya mereka adalah para isteri dan keluarga teroris yang sudah lama terlibat dalam aksi-aksi pengeboman di Indonesia, isteri dan keluarga para jihadis di Suriah, Lebanon dan Turki. Para suami atau keluarga mereka adalah anggota Jamaah Islamiyah, Jamaah Ansharut Tauhid, gerakan Negara Islam Indonesia, ISIS, Salafi Jihadis dan organisasi Islam radikal lain.

Menarik disebutkan, sebagian besar mereka bukanlah perempuan bodoh dan tidak terdidik. Kebanyakan mereka lulusan perguruan tinggi, selebihnya lulusan pesantren dan Sekolah Menengah Atas. Lalu, dari aspek ekonomi, mereka tidak selalu dari kelompok miskin, tidak sedikit dari kalangan menengah ke atas. Profesi mereka pun beragam dan 
Perempuan Dalam Gerakan...

sebagian cukup menjanjikan, misalnya berkarir sebagai dosen, guru, muballighah, ustazah, dokter, karyawan, aktivis organisasi dan pedagang online. Sisanya, sebagai pelayan toko, buruh migran, dan pekerja pabrik.

Sebagian mereka direkrut melalui pernikahan, lalu suami mendoktrin mereka dengan pemahaman Islam radikal. Artinya, mereka sengaja dinikahi untuk dijejali ideologi radikal, bahkan sebagian perempuan dinikahi ketika suami masih berada di penjara. Sebaliknya, tidak sedikit dari mereka justru didoktrinasi terlebih dahulu baru dinikahi. Sebagian dari mereka mendapatkan indoktrinasi yang sangat masif dari teman dekat suami atau dari sesama perempuan yang telah lama aktif dalam jaringan terorisme.

Menarik diketahui, tidak sedikit perempuan buruh migran berhasil direkrut dalam gerakan terorisme. Mengapa? Karena umumnya mereka punya uang, mandiri, dan berani serta yang paling penting mereka punya pengalaman bepergian ke luar negeri sehingga mudah dijadikan sebagai agen kurir atau pembawa pesan-pesan rahasia. Mereka juga umumnya pengguna aktif internet. Sebagian mereka terpapar ideologi radikalisme lewat internet ketika bekerja di luar negeri. Pertemuan mereka dengan suami dan kelompoknya umumnya terjadi melalui jaringan sosial media, seperti facebook.

Perempuan buruh migran seringkali mengidap kekecewaan dan frustrasi yang sangat dalam akibat perlakuan diskriminatif dan kekerasan fisik yang mereka alami ketika bekerja. Umumnya mereka mengalami berbagai trauma psikologis selama bekerja di luar negeri. Patologi psikis tersebut membuat sebagian mereka mudah menerima pengaruh apa pun yang dianggap dapat menolong mereka keluar dari situasi mencekam tersebut. Sebagian mereka sangat membutuhkan mekanisme pertahanan diri (self defence mechanism) untuk bertahan dari berbagai tekanan sosial. Aksi-aksi terorisme mebuat mereka menemukan kebermaknaan hidup.

Dian Yulia Novi, pelaku bom bunuh diri awalnya tertarik mempelajari Islam melalui internet dan jejaring sosial. Pelajaran agama tersebut membuatnya tertarik pada perjuangan Islam di Suriah. Berikutnya, dia mengalami proses indoktrinisasi yang intens 
melalui facebook dan situs-situs radikal, termasuk situs jihad online yang dikelola jaringan Aman Abdurrahman.

Teknologi komunikasi menjadi sarana efektif bagi jaringan teroris untuk menyebarkan paham radikal sambil melakukan rekrutmen anggota. Brooking Institute menyebutkan, tahun 2014 saja ada 46.000 akun twitter atas nama ISIS dan masing-masing memiliki rata-rata 1000 pengikut. Setiap hari, setidaknya 90.000 konten bermuatan hate speech, kekerasan dan ekstrimisme dimuat ke ranah internet dan pengguna twitter di Indonesia menyumbang $20 \%$ atas percakapan tersebut.Analisis intelijen mengamati bahwa mereka paling canggih menggunakan internet serta mengisinya dengan beragam konten propaganda yang dibuat secara professional dan mampu menghipnotis pembacanya. (Debbie Affianty :2017)

Tugas dan peran perempuan dalam gerakan terorisme cukup beragam dan signifikan. Di antaranya, mereka berperan sebagai pendidik (Educator); agen perubahan (Agent of change); pendakwah(Campaigner); pengumpul dana (Fund raiser); perekrut (Recruiter); penyedia logistik (Logistic arranger); pengantin atau pelaku bom bunuh diri (suicide bombers); kurir antar kota, antar negara; penghubung rahasia (mata-mata); agen radikal; pengikut dan pendamping setia dari suami yang terlebih dahulu menjadi teroris.

Selain Dian yang berperan sebagai pengantin atau pelaku bom bunuh diri, sejumlah nama dapat disebutkan, seperti Munfiatun (2006), isteri Noordin M. Top berperan sebagai agen rahasia yang menyembunyikan keberadaan para teroris. Siti Rahmah (2008), isteri kedua Noordin M. Top berperan sebagai perekrut dan penyedia logistik. Putri Munawaroh, isteri Adib Susilo berperan penting sebagai agen radikal.Tugasnya merekrut perempuan muda untuk menjadi pelaku bom bunuh diri. Sedangkan Noor Azmi Tibyani, isteri Cahya Fitriyanta memiliki peran khusus sebagai pencari dana untuk membiayai pelatihan militer Poso tahun 2008 dengan menggunakan rekeningnya. Ummu Delima (2014), isteri Santoso berperan penting mendukung suami dalam gerakan terorisme Poso. Lalu, Ika Puspita Sari (2016) di Purworejo berperan sebagai subyek, pelaku bom bunuh diri. 
Perempuan Dalam Gerakan...

Sebagian mereka direkrut melalui pernikahan, suami sendiri yang melakukan upaya terencana menanamkan ideologi radikal dengan "cuci otak". Artinya, mereka sengaja dinikahi untuk selanjutnya didoktrin dengan ideologi radikal. Pernikahan mereka sebagian berlangsung secara normal, namun tidak sedikit menikah dalam penjara. Sebagian lagi dinikahi belakangan setelah mereka menerima doktrin radikal tersebut. Tidak sedikit dari mereka mendapatkan indoktrinasi yang sangat masif dari teman dekat suami atau dari sesama perempuan yang telah terlebih dahulu aktif dalam jaringan tersebut.

\section{PENUTUP}

Sulit untuk tidak mengatakan bahwa meski perempuan berperan sebagai subyek pelaku bom dan aktor utama dalam gerakan terorisme, namun sejatinya mereka justru hanyalah korban. Korban dari ideologi suami atau keluarga, korban indoktrinasi agama yang tidak memihak kemanusiaan, korban stigmatisasi dari masyarakat, korban media, dan juga korban dari ekses konflik. Perempuan lagi-lagi hanyalah korban dari kondisi yang diciptakan oleh para elit kekuasaan patriarki.

Karena itu, upaya mengatasinya harus dengan pendekatan dan sentuhan kemanusiaan dan memberi tempat kepada mereka dalam pergaulan sosial arus-utama. Pendekatan keamanan dengan kekuatan militeristik harus ditinjau ulang. Perlu disadari bahwa penggunaan pendekatan keamanan semata hanya akan membuat kelompok tersebut mati suri. Di balik itu, mereka tetap beroperasi di bawah tanah dan lebih aktif menata ulang sel-sel rahasia mereka yang suatu saat bergelora dan berujung dengan ledakan maut yang lebih dahsyat.

Hal paling penting adalah keinginan politik yang kuat dari negara dan seluruh elemen civil society untuk mengikis akar-akar penyebab terorisme, seperti kemiskinan, pengangguran, korupsi, kesenjangan dan ketidakadilan sosial yang sudah sedemikian akut di masyarakat. Betul bahwa tidak semua anggota kelompok ini adalah orang-orang miskin, seperti Dr. Azhari. Namun, narasi kemiskinan dan ketidakadilan menjadi pintu utama penyebaran ideologi radikal mereka. 
Sesuai kodratnya, perempuan lebih mudah direkrut menjadi agen perdamaian (agent of disengagement). Kalau mereka bisa direkrut menjadi teroris seharusnya lebih mudah mengajak mereka menjadi agen perdamaian. Karena secara alami perempuan diciptakan dengan sebuah rahim untuk merawat keberlangsungan kehidupan manusia. Perempuan memiliki instink dan passion keibuan yang memungkinkannya lebih mudah untuk menjalani tugas-tugas menjaga keberlangsungan hidup, mereda konflik dan memelihara perdamaian. Untuk itu, diperlukan strategi yang lebih manusiawi, komprehensif dan pendekatan yang jauh dari maskulin (keamanan), namun mengena kepada mereka yang terlibat gerakan terorisme.

Indonesia terlalu penting untuk diserahkan dan dipertaruhkan sepenuhnya kepada pemerintah dan politisi. Masyarakat perlu terlibat mengikis terorisme. Sangat penting bagi semua elemen dalam masyarakat, khususnya pemimpin agama dan ormas keislaman mempromosikan ajaran Islam yang mengedepankan nilai-nilai humanis, keadilan, kesetaraan, toleransi dan perdamaian. Sebab, esensi Islam adalah memanusiakan manusia dan membangun masyarakat yang berkeadilan dan berkeadaban. Islam seharusnya menjadi rahmat bagi semua makhluk di alam semesta (rahmatan lil 'alamin).

Terakhir, negara semestinya memikirkan strategi counter-ideology terrorism yang komprehensif dan mengombinasikannya dengan upaya menata pluralisme dalam kerangka demokrasi yang berkeadaban. Negara perlu menegaskan kembali prinsip demokrasi seperti terbaca dalam konstitusi dan Pancasila. Konstitusi danPancasila menjadi kesepakataan politik para pendiri bangsa yang harus dirawat dan dipertahankan. Para penyelenggara negara dituntut untuk menegaskan prinsip ini bukan semata sebagai semboyan dan jargon tapi terwujud secara nyata dalam berbagai bentuk peraturan perundang-undangan, kebijakan, dan perilaku aparatur negara dan masyarakat.

\section{DAFTAR PUSTAKA}

Abdullah Darraz (2017), Reformulasi Ajaran Islam: Jihad, Khilafah dan Terorisme, Mizan, Bandung.

Arendt, Hannah(1968). On Revolution, New York: Viking 
Frisch, Hillel dan Efraim Inbar (eds) (2008), Radical Islam and International Security: Challenges and Responses, Rouledge, London.

Karen Armstrong,(2003),Sejarah Tuhan, Penerbit Mizan, Bandung, Cetakan IV.

Khaled Abou El-Fadl (2005), The Great Theft: Wrestling Islam from the Extremists, Harper Collins.

Muhammad Saeed Al-Qahthany, Al-Walla wa Al-Barra'min Mafahim 'Aqidah Al-Salaf, Muqaddimah, t.th,

Speckhard, Anne and Khapta AkhmedovaBlack Widows: The Chechen Suicide Terrorist, McLean, VA: Advances Press. 2004.

Speckhard, Anne. Bride of ISIS: One Young Women's Path into Homegrown Terrorism, McLean, VA: Advances Press. 2015.

Https://www.tempo.co/read/fokus/2016/12/15/3402/pola-rekrutmen-teroris-jadikanperempuan-sebagai-pengantin\#W2jOXFtUBprbOfxe 